\title{
ANALISIS METODE ECONOMIC VALUE ADDED UNTUK MENILAI KINERJA KEUANGAN PADA PT. UNILEVER INDONESIA
}

\author{
Muhammad Hefrizal \\ Program Studi Akuntansi, Politeknik LP3I Medan \\ Laelisneni \\ Program Studi Akuntansi, Politeknik LP3I Medan \\ *Corresponding author: E-mail: comhefrizalm@gmail.com, laelisneni@yahoo.com
}

\begin{abstract}
Abstrak
EVA merupakan salah satu metode yang mengukur kinerja keuangan perusahaan untuk menentukan nilai tambah, yang nilai tambah tersebut digunakan oleh para pemilik modal sebagai acuan dalam menentukan investasi pada perusahaan tertentu. Manfaat dari EVA sebagai tolak ukur dalam menilai kinerja keuangan terhadap para pemilik modal yang berminat menginvestasikan modalnya di perusahaan. Adapun tujuan penulis melakukan penelitian ini adalah untuk mengetahui kinerja keuangan perusahaan dengan menggunakan metode EVA menunjukkan perkembangan positif atau negatif pada periode 2014 - 2016 . Penelitian ini menggunakan metode analisis deskriptif kuantitatif. Metode analisis data dalam bentuk angka yang kemudian dideskripsikan sebab akibat terjadinya variabel penelitian tersebut. Hasil analisis metode EVA untuk mengukur kinerja keuangan menunjukkan perkembangan yang positif dalam waktu 3 tahun yakni EVA > dari 0, maka telah terjadi nilai tambah ekonomis dan kinerja keuangan perusahaan dapat dikatakan baik.
\end{abstract}

\section{Kata Kunci : Economic Value Added, Kinerja Keuangan}

\begin{abstract}
EVA is one method that measures the company's financial performance to determine the added value, the added value is used by the owners of capital as a reference in determining the investment in a particular company. The benefits of EVA as a benchmark in assessing the financial performance of capital owners who are interested in investing capital in the company. The purpose of the authors conducted this study is to determine the financial performance of companies using EVA method showed positive or negative development in the period 2014 2016. This study uses descriptive quantitative analysis method. Methods of data analysis in the form of numbers which are then described as the cause of the variables of the study. The result of EVA method analysis to measure financial performance shows positive development within 3 years ie EVA> from 0 , hence has happened value added economics and company financial performance can be said good.
\end{abstract}




\section{PENDAHULUAN}

Economic Value Added (EVA) merupakan salah satu metode pengukuran kinerja yang ditemukan pertama kali oleh G. Bennet Stewart dan Joel M. Stren.Mereka berdua merupakan seorang analis keuangan dari perusahaan Sten Stewart dan Co pada tahun 1993. EVA merupakan salah satu metode yang mengukur kinerja keuangan perusahaan untuk menentukan nilai tambah, yang nilai tambah tersebut digunakan para pemilik modal sebagai acuan dalam menentukan investasi di suatu perusahaan. Manfaat dari EVA sebagai tolak ukur dalam menilai kinerja keuangan bagi para pemilik modal yang berminat menginvestasikan modalnya di perusahaan.

Pada penelitian terdahulu yang dilakukan oleh Astuti (2014), yang berjudul Economic Value Added (EVA) Sebagai Alat Penilaian Kinerja Pada PT Gudang Garam TBK Tahun 2011 - 2013 menunjukkan bahwa pada tahun 2011 bernilai negatif atau EVA > dari 0 , maka pada tahun tersebut terjadi nilai tambah ekonomis, namun pada tahun 2012 dan 2013 EVA yang dihasilkan bernilai negatif atau EVA < dari 0, maka pada tahun tersebut tidak terjadi nilai tambah ekonomis.

PT. Unilever mengukur kinerja keuangan menggunakan analisis rasio likuiditas, rasio solvabilitas dan rasio profitabilitas.Rasio tersebut tidak memperhatikan biaya modal sehingga sulitnya mengetahui apakah perusahaan menciptakan nilai atau tidak dikarenakan diabaikannya biaya modal. Penulis memilih objek penelitian pada PT Unilever dikarenakan selama 3 tahun, dari tahun 2014 - 2016 beban usaha mengalami peningkatan yaitu beban pemasaran dan penjualan dan beban umum dan administrasi, naiknya beban tersebut menyebabkan pendapatan atau laba usaha perusahaan mengalami kenaikan dan penurunan (fluktuatif). Maka dari itu penulis tertarik melakukan penelitian dengan judul "Analisis Metode Economic Value Added Untuk Menilai Kinerja Keuangan Pada PT. Unilever Indonesia Tbk Yang Terdaftar Di BEI".

Berdasarkan latar belakang itu, maka yang menjadi permasalahan pada penelitian ini adalah, Apakah kinerja keuangan perusahaan dengan menggunakan metode EVA menunjukkan perkembangan positif atau negatif pada periode 2014 - 2016 .

Adapun tujuan penulis melakukan penelitian ini adalah Untuk mengetahui kinerja keuangan perusahaan dengan menggunakan metode EVA menunjukkan perkembangan positif atau negatif pada periode 2014 - 2016.

\section{Definisi Laporan Keuangan}

Menurut Hermanto dan Agung (2015 : 1) Laporan keuangan merupakan suatu ringkasan transaksi yang dilakukan dari perusahaan yang terjadi selama 1 periode akuntansi atau 1 tahun buku, adapun manajemen membuat laporan keuangan bertujuan untuk membebaskan diri dari tanggung jawab yang dibebankan kepadanya oleh para pemilik perusahaan.

\section{Tujuan Penyusunan Laporan Keuangan}


Menurut Kasmir (2017 : 89) beberapa tujuan pembuatan atau penyusunan laporan keuangan yaitu :

1. Memberikan informasi tentang jenis dan jumlah aktiva (harta) yang dimiliki perubahan pada saat ini.

2. Memberikan informasi tentang jenis dan jumlah kewajiban dan modal yang dimiliki perusahaan pada saat ini

3. Memberikan informasi tentang jenis dan jumlah pendapatan yang diperoleh pada suatu periode tertentu.

4. Memberikan informasi tentang jumlah biaya dan jenis biaya yang dikeluarkan perusahaan dalam suatu periode tertentu.

5. Memberikan informasi tentang perubahan yang terjadi terhadap aktiva, pasiva, dan modal perusahaan.

6. Memberikan informasi tentang kinerja manajemen perusahaan dalam suatu periode.

7. Memberikan informasi tentang catatan atas laporan keuangan.

8. Informasi keuangan lainnya.

\section{Analisis Laporan Keuangan}

Menurut Hery (2014 : 113) Analisis Laporan keuangan merupakan suatu metode yang membantu para pengambil keputusan untuk mengetahui kekuatan dan kelemahan perusahaan melalui informasi yang didapat dari laporan keuangan. Analisis laporan keuangan dapat membantu manajemen untuk mengidentifikasi kekurangan atau kelemahan yang ada dan kemudian membuat keputusan yang rasional untuk memperbaiki kinerja perusahaan dalam rangka mencapai tujuan perusahaan.Analisis laporan keuangan juga berguna bagi investor dan kreditor dalam pengambilan keputusan investasi dan kredit.

\section{Tujuan Analisis Laporan Keuangan}

Menurut Wahyudiono (2014 : 11) Tujuan analisis laporan keuangan sendiri pada hakikatnya adalah untuk membantu pemakai dalam memperkirakan masa depan perusahaan dengan cara membandingkan, mengevaluasi dan menganalisis kecenderungan dari berbagai aspek keuangan perusahaan.

Menurut Hery (2014 : 114) secara umum tujuan dan manfaat analisis laporan keuangan adalah :

1. Untuk mengetahui posisi laporan keuangan perusahaan dalam suatu periode tertentu, baik aset, liabilitas, ekuitas maupun hasil usaha yang telah dicapai selama beberapa periode.

2. Untuk mengetahui kelemahan kelemahan yang menjadi kekurangan perusahaan.

3. Untuk mengetahui kekuatan kekuatan yang menjadi keunggulan perusahaan.

4. Untuk menentukan langkah langkah perbaikan yang perlu dilakukan di masa mendatang, khususnya yang berkaitan dengan 
posisi keuangan perusahaan saat ini.

5. Untuk melakukan penilaian kinerja manajemen.

6. Sebagai pembanding dengan perusahaan sejenis, terutama mengenai hasil yang telah dicapai.

\section{Definisi Kinerja Keuangan}

Definisi Kinerja Keuangan menurut para ahli :

Menurut Sawir (Adiguna, 2017 : 435) "kinerja keuangan merupakan kondisi yang mencerminkan keadaan keuangan suatu perusahaan berdasarkan sasaran, standar dan kriteria yang telah ditetapkan".

Menurut Fahmi (Adiguna, 2017 : 435) kinerja keuangan adalah suatu analisis yang dilakukan untuk melihat sejauh mana suatu perusahaan telah melaksanakan dengan menggunakan aturan - aturan pelaksanaan keuangan secara baik dan benar.

\section{Economic Value Added (EVA)}

Menurut O’Byrne (Astuti, 2014 : 11) Economic Value Added adalah alat komunikasi yang dapat dijangkau oleh manajer lini yang akhirnya mendorong kinerja perusahaan dan untuk menghubungkan dengan pasar modal".

Ada beberapa langkah dalam Menghitung EVA sebagai berikut :

1. Net Operating After Tax (NOPAT)
Menurut Tunggal (Endang, 2016 : 36) NOPAT pada dasarnya merupakan tingkat keuntungan yang diperoleh dari modal yang ditanam, NOPAT bisa dihitung dengan rumus : NOPAT $=$ EBIT TAX

2. Invested Capital (IC)

Menurut Tunggal (Endang,2016 : 36) IC merupakan hasil penjabaran perkiraan dalam neraca untuk melihat besarnya modal yang diinvestasikan perusahaan oleh kreditur dan seberapa besar modal yang di investasikan dalam perusahaan, IC bisa dihitung dengan rumus : Invested Capital = Total Hutang \& Ekuitas - Hutang Jangka Pendek

3. Weighted Average Cost Of Capital (WACC)

Menurut Young (Endang, 2016 : 36) WACC sama dengan jumlah biaya dari setiap komponen modal hutang jangka pendek, hutang jangka panjang, dan ekuitas pemegang saham ditimbang berdasarkan proporsi relatifnya dalam struktur modal perusahaan pada nilai pasar, WACC bisa dihitung dengan rumus : $\mathbf{W A C C}=$ $\{(D \times$ rd $)(1$ - Tax $)+($ E x Re $)\}$

Keterangan : D : Tingkat Modal

Rumus $=>$ Total Hutang / Total Hutang \& Ekuitas x 100\%

Rd :Cost Of Debt (Biaya 


$$
\text { Rumus }=>\text { Beban bunga }
$$

$$
\text { Tax : Pajak }
$$

Rumus => Beban Pajak Penilaian Kinerja Keuangan

/ Laba Bersih Sebelum Pajak x 100\%

\section{E : Ekuitas}

Rumus $=>$ Total Ekuitas

/ Total Hutang \& Ekuitas x 100\%

(Biaya Modal)

$$
\text { Re :Cost of Equity }
$$

Rumus = Laba bersih setelah pajak / total ekuitas x 100\%

\section{Capital Charge (CC)}

Menurut Tunggal (Endang, 2016 : 36) CC merupakan aliran kas yang dibutuhkan untuk mengganti para investor atas risiko usaha dari modal yang ditanam, CC bisa dihitung dengan rumus : Capital Charge = WACC x Invested Capital

5. Economic Value Added (EVA)

Menurut Tunggal (Endang, 2016 : 35) perusahaan apabila memiliki nilai EVA positif, maka dapat dikatakan bahwa manajemen perusahaan tersebut mampu menciptakan nilai tambah bagi perusahaannya. Sebaliknya apabila EVA negatif, maka perusahaan mengalami distructing / destroying value. EVA bisa dihitung dengan rumus : EVA $=$ NOPAT $\times$ Capital Charge

Menurut Rudianto (Adiguna, 2017 : 435) penilaian kinerja keuangan perusahaan diukur dengan ketentuan :

1. Jika EVA > 0, maka kinerja keuangan perusahaan dapat dikatakan baik, sehingga terjadi proses nilai ekonomisnya.

2. Jika EVA $=0$, maka kinerja keuangan perusahaan secara ekonomis dalam keadaan impas.

3. Jika EVA $<0$, maka kinerja keuangan perusahaan tersebut dikatakan kurang baik karena laba yang diperoleh tidak memenuhi harapan pemilik modal, sehingga tidak terjadi pertambahan nilai pada ekonomis perusahaan.

\section{Manfaat dan Keunggulan Metode EVA}

Menurut Abdullah (Endang, 2016 : 37) keunggulan yang dimiliki metode EVA di antaranya adalah :

1. Alat ukur yang dapat berdiri sendiri, tidak memerlukan adanya suatu perbandingan dengan perusahaan sejenis dalam industri dan tidak perlu membuat suatu analisis kecenderungan dengan tahun - tahun sebelumnya.

2. Alat pengukur kinerja perusahaan yang melihat segi ekonomis dalam 
pengukurannya, yaitu dengan memperhatikan harapan - harapan pada pemilik modal secara adil. Derajat keadilan EVA dinyatakan dengan ukuran tertimbang dari struktur modal yang ada dan berpedoman pada nilai pasar, bukan nilai buku.

3. Dapat dipakai sebagai tolak ukur dalam pemberian bonus kepada karyawan. EVA merupakan tolak ukur yang tepat untuk menjalankan stakeholder satisfaction concept, yakni memperhatikan pelanggan dan pemilik modal.

Menurut Shidarta (Astuti, 2014 : 14) beberapa manfaat yang dapat diperoleh dari EVA adalah :

1. Penilaian kinerja dengan menggunakan pendekatan EVA menyebabkan perhatian manajemen sesuai dengan keputusan pemegang saham.

2. Dengan EVA para manajer akan berpikir dam bertindak seperti pada halnya pemegang saham yaitu memilih investasi yang memaksimalkan tingkat pengembalian dan meminimalkan tingkat biaya modal sehingga nilai perusahaan dapat dimaksimalkan.

3. EVA membuat manajer memfokuskan perhatian pada kegiatan yang menciptakan nilai dan mengevaluasi kinerja berdasar kriteria memaksimalkan nilai perusahaan.

4. EVA dapat digunakan untuk mengidentifikasikan kegiatan atau praktik yang memberikan pengembalian yang lebih tinggi dari pada biaya modal.

5. EVA akan menyebabkan perusahaan untuk lebih memperhatikan kebijakan struktur modal.

\section{METODE PENELITIAN}

Penelitian dilakukan pada PT Unilever Indonesia Tbk yang terdaftar di Bursa Efek Indonesia (BEI) dari tahun 2014 - 2016.

Jenis data yang digunakan adalah data sekunder. Menurut Sudaryono (2014 : 13) "Data sekunder adalah data yang diperoleh dalam bentuk jadi dan sudah diolah pihak lain, yang biasanya dalam bentuk publikasi". Dan Sumber data yang digunakan adalah sumber data eksternal.data yang dibutuhkan pada penelitian ini berupa data laporan keuangan yang didapat dari Bursa Efek Indonesia. Data laporan keuangan tersebut adalah laporan neraca, laporan laba rugi dan laporan perubahan modal.

Penelitian ini menggunakan metode dokumentasi dan studi pustaka sebagai metode pengumpulan data. Metode Dokumentasi adalah Metode pengumpulan data yang didapat dari dokumen dokumen yang tersimpan, baik berupa catatan, buku, koran, majalah, internet dan lainnya. Metode Studi Pustaka adalah Metode yang didapat dari literatur literatur dan hasil penelitian terdahulu yang digunakan sebagai pelengkap landasan teori. 
Penelitian ini menggunakan metode analisis deskriptif kuantitatif.Metode analisis data dalam bentuk angka yang kemudian dideskripsikan sebab akibat terjadinya variabel penelitian tersebut.

\section{HASIL PENELITIAN}

Berikut ini adalah langkah - langkah perhitungan metode EVA untuk menilai kinerja keuangan :

1. Menghitung Net Operating After Tax (NOPAT)

Tabel 1 Net Operating After Tax

(jutaan rupiah)

\begin{tabular}{|c|c|c|c|}
\hline Tahun & Laba Sebelum Pajak & Beban Pajak & NOPAT \\
\hline 2014 & 8.013 .258 & 2.000 .932 & 6.012 .326 \\
2015 & 7.939 .401 & 1.977 .685 & 5.961 .716 \\
2016 & 8.707 .661 & 2.181 .213 & 6.526 .448 \\
\hline
\end{tabular}

Sumber : Penulis Pengolah Data (2018)

\section{Menghitung Invested Capital (IC)}

Tabel 2 Invested Capital

(jutaan rupiah)

\begin{tabular}{|c|c|c|c|}
\hline Tahun & Total Hutang \& Ekuitas & Hutang Jangka Pendek & IC \\
\hline 2014 & 14.280 .670 & 8.864 .242 & 5.416 .428 \\
2015 & 15.729 .945 & 10.127 .542 & 5.602 .403 \\
2016 & 16.745 .695 & 10.878 .074 & 5.867 .621 \\
\hline
\end{tabular}

Sumber : Penulis Pengolah Data (2018)

3.

\section{Menghitung Weight Average Cost of Capital (WACC)}

a. Menghitung WACC tahun 2014

1. Tingkat Modal (D) $=9.534 .156 /$

$14.280 .670 \times 100 \%=66,76 \%$

2. Biaya Hutang $(\mathrm{Rd})=96.064 /$

$9.534 .156 \times 100 \%=1 \%$
3. $\operatorname{Tax}$ $=2.000 .932 /$

$7.927 .652 \times 100 \%=25,23 \%$

4. Ekuitas (E) $=4.746 .514 /$

$14.280 .670 \times 100 \%=33,23 \%$

5. Biaya Modal $(\mathrm{Re}) \quad=5.926 .720 /$

$4.746 .514 \times 100 \%=124,86 \%$

b. Menghitung WACC tahun 2015

1. Tingkat Modal $(\mathrm{D})=10.902 .585$

/ $15.729 .945 \times 100 \%=69,31 \%$ 

2. Biaya Hutang $(\mathrm{Rd})=120.527 /$
1. Tingkat Modal (D) $=12.041 .437$
$10.902 .585 \times 100 \%=1,10 \%$
/ $16.745 .695 \times 100 \%=71,90 \%$
3. $T a x$
$=1.977 .685 /$
2. Biaya Hutang $(\mathrm{Rd})=143.244 /$
$7.289 .490 \times 100 \%=25,25 \%$
$12.041 .437 \times 100 \%=1,18 \%$
4. Ekuitas (E) $\quad=4.827 .360 /$
3. $\operatorname{Tax}$
$=2.181 .213 /$
$15.729 .945 \times 100 \%=30,68 \%$
$8.571 .865 \times 100 \%=25,44 \%$
5. Biaya Modal $(\mathrm{Re}) \quad=5.851 .805 /$
4. Ekuitas (E) $=4.704 .258 /$
$4.827 .360 \times 100 \%=121,22 \%$
$16.745 .695 \times 100 \%=28,09 \%$
c. Menghitung WACC tahun 2016
5. Biaya Modal $(\mathrm{Re})=6.390 .652 /$
$4.704 .258 \times 100 \%=135,84 \%$

Tabel 3 Weight Average Cost Of Capital

\begin{tabular}{|c|c|c|c|c|c|c|}
\hline Tahun & $\begin{array}{c}\text { Tingkat } \\
\text { Modal }\end{array}$ & $\begin{array}{c}\text { Biaya } \\
\text { Hutang }\end{array}$ & Pajak & $\begin{array}{c}\text { Tingkat } \\
\text { Ekuitas }\end{array}$ & $\begin{array}{c}\text { Biaya } \\
\text { Modal }\end{array}$ & WACC \\
\hline 2014 & $66,76 \%$ & $1 \%$ & $25,23 \%$ & $33,23 \%$ & $124,86 \%$ & $4,64 \%$ \\
2015 & $69,31 \%$ & $1,10 \%$ & $25,25 \%$ & $30,68 \%$ & $121,22 \%$ & $4,28 \%$ \\
2016 & $71,90 \%$ & $1,18 \%$ & $25,44 \%$ & $28,09 \%$ & $135,84 \%$ & $4,44 \%$ \\
\hline
\end{tabular}

Sumber : Penulis Pengolah Data (2018)

\section{Menghitung Capital Charge (CC)}

Tabel 4 Capital Charge

(jutaan rupiah)

\begin{tabular}{|c|c|c|c|}
\hline Tahun & WACC & Invested Capital & Capital Charge \\
\hline 2014 & $4,64 \%$ & 5.416 .428 & 251.322 \\
2015 & $4,28 \%$ & 5.602 .403 & 239.782 \\
2016 & $4,44 \%$ & 5.867 .621 & 260.522 \\
\hline
\end{tabular}

Sumber : Penulis Pengolah Data (2018)

\section{Menghitung Economic Value Added (EVA)}

Tabel 5Economic Value Added

(jutaan rupiah)

\begin{tabular}{|c|c|c|c|}
\hline Tahun & NOPAT & Capital Charge & EVA \\
\hline 2014 & 6.012 .326 & 251.322 & 5.761 .004 \\
2015 & 5.961 .716 & 239.782 & 5.721 .934 \\
2016 & 6.526 .448 & 260.522 & 6.265 .926 \\
\hline
\end{tabular}

Sumber : Penulis Pengolah Data (2018)

\section{Pembahasan Hasil Penelitian}


Tabel 6 Pembahasan Hasil Penelitian

\begin{tabular}{|c|c|c|c|c|c|c|}
\hline Tahun & $\begin{array}{c}\text { NOPAT } \\
\text { (1) }\end{array}$ & $\begin{array}{l}\text { IC } \\
\text { (2) }\end{array}$ & $\begin{array}{c}\text { WACC } \\
\text { (3) }\end{array}$ & $\begin{array}{c}C C \\
(2 \times 3)\end{array}$ & $\begin{array}{c}\text { EVA } \\
\text { (1) }-(2 \times 3)\end{array}$ & Kriteria \\
\hline 2014 & 6.012 .326 & 5.416 .428 & $4,64 \%$ & 251.322 & 5.761 .004 & dari 0 \\
\hline 2015 & 5.961 .716 & 5.602 .403 & $4,28 \%$ & 239.782 & 5.721 .934 & $>$ dari 0 \\
\hline 2016 & 6.526 .448 & 5.867 .621 & $4,44 \%$ & 260.522 & 6.265 .926 & $>$ dari 0 \\
\hline
\end{tabular}

Sumber : Penulis Pengolah Data (2018)

Hasil perhitungan dari tabel tersebut menunjukkan bahwa dari tahun 2014 - 2016 diperoleh nilai yang positif atau EVA > dari 0.Artinya kinerja keuangan perusahaan dikatakan baik.Meskipun laba usaha yang diperoleh mengalami fluktuatif dari tahun ke tahun.

Beberapa hal yang menyebabkan kinerja keuangan menciptakan nilai positif :

1. Net Operating After Tax (NOPAT) Semakin besar pendapatan atau laba usaha yang didapat maka NOPAT yang diperoleh akan semakin besar pula. NOPAT yang diperoleh akan mempengaruhi besarnya EVA. Apabila NOPAT lebih besar dari biaya modal, maka EVA yang diperoleh bernilai positif begitu juga sebaliknya.

2. Invested Capital / Modal Investasi (IC)

Besar kecilnya Modal Investasi akan mempengaruhi Biaya Modal. Cara mendapatkan Biaya Modal yaitu WACC dikali Modal Investasi. semakin tinggi Modal Investasi yang didapat semakin tinggi pula Biaya Modal yang dihasilkan begitu juga sebaliknya.

3. Capital Charge / Biaya Modal (CC)
Besarnya EVA tergantung dari Biaya Modal. Semakin kecil Biaya Modal yang didapat maka semakin besar pula EVA yang diperoleh. Biaya Modal dipengaruhi oleh besarnya Modal Investasi. Karena Modal Investasi didapat dengan mengurangkan total utang dan ekuitas dengan utang jangka pendek. Besar kecilnya utang jangka pendek akan mempengaruhi Modal Investasi.

\section{KESIMPULAN}

Adapun kesimpulan dari hasil penelitian tersebut adalah :

1. Analisis kinerja keuangan menggunakan metode Economic Value Added (EVA) menunjukkan perkembangan yang positif selama 3 tahun terakhir yakni EVA > dari 0, maka telah terjadi nilai tambah ekonomis dan kinerja keuangan perusahaan dapat dikatakan baik

2. Walaupun laba perusahaan mengalami fluktuatif, akan tetapi hasil analisis EVA menunjukkan kinerja keuangan perusahaan bernilai positif maka harapan para pemilik modal dapat terpenuhi dengan baik, harapan para pemilik 
modal adalah mendapatkan investasi yang sama atau lebih.

\section{DAFTAR PUSTAKA}

A, I.N. (2017) analisis kinerja keuangan dengan menggunakan metode EVA pada perusahaan plastik dan kemasan yang terdaftar di bursa efek Indonesia tahun 2011 - 2015, Jurnal EMBA, Vol. 5, $423-442$.

A, N.B (2014) Economic Value Added (EVA) Sebagai Alat Penilaian Kinerja Pada PT. Gudang Garam Tbk Tahun 2011 - 2013. Tugas Akhir, Program Studi Akuntansi Diploma III Fakultas Ekonomi Universitas Negeri Yogyakarta.

E, (2016) Pengukuran Kinerja Keuangan PT. Mayora Indah Tbk Dengan Pendekatan Metode Economic Value Added (EVA), Jurnal Akuntansi Politeknik Sekayu, Vol. IV, 32 - 44.

H, B. dan A, Mulyo (2015), Analisa Laporan Keuangan, Jakarta : PT. Lentera Ilmu Cendikia.

H, (2014), Analisis Kinerja Manajemen, Jakarta : PT. Grasindo.

K, (2017), Pengantar Manajemen Keuangan, Edisi 2, Jakarta : PT. Kencana Pranada Media Group.

S, (2014), Aplikasi Statistik Untuk Penelitian, Jakarta : PT. Lentera Ilmu Cendikia.
W, B. (2014), Mudah Membaca Laporan Keuangan, Cetakan 1, Jakarta : PT. Raih Asa Sukses (Penebar Swadaya Grup). 